\title{
The Uniqueness of Malay Zapin Dance Choreography
}

\author{
Riri Triyani*, Juju Masunah, Trianti Nugraheni \\ Undergraduate School \\ Universitas Pendidikan Indonesia \\ Bandung, Indonesia \\ *riritriyani@upi.edu
}

\begin{abstract}
Zapin dance was one of the groups of Malay dances that had been influenced by the Arabs. The word Zapin came from the Arabic word "Zafn" which meant the movement of the foot quickly following the beat. The Zapin dance developed in the Malay indigenous community, which used to be performed only by male dancers. The Zapin dance was divided into three parts, the first was the opening movement, the second was the core movement, and the last was the closing movement, some of which contained philosophical values. Zapin dance had an educational and entertaining purpose because the music and dance contained educational elements and it was used as a medium for Islamic preaching. The purpose of this study was to discuss where the unique movements in the Zapin Dance were located. This study employed a qualitative approach using descriptive-analytical research methods. The data was collected by analyzing journals and literature, and documentation studies. The results of this study explained that the uniqueness of Zapin Dance lied in the choreography, namely the direction of motion and rhythmic stomping of the feet.
\end{abstract}

Keywords-Zapin dance, unique, choreography

\section{INTRODUCTION}

In Nusantara, Zapin is known in two types, namely Arabic Zapin and Malay Zapin [1]. Arabic Zapin has been changing slowly and is still being maintained by people of Arab descent, while Malay Zapin has grown because of local experts and adapted to the environmental conditions in the local community. Ibnur states that if the Arabic Zapin is only known to have one style only, then the Malay Zapin has a very diverse style depending on the local language or dialect in which the Zapin grows and develops [1].

Zapin dance originally came from Arabia, namely Yemen, where the Zapin dance was used as an entertainment among the Palace, especially in the country of the Zapin Dance [2]. Then, it was brought from Hadramaut, by Arab traders in the early 16th century and came into the Johor Lingga. In 1824, it grew and developed in the kingdoms of Johor, Riau, and Lingga. Only then did the Zapin Dance spread to around Malay areas such as Malaysia, Singapore, Indonesia, and Brunei sDarussalam [2].

The entry of the Zapin Dance in Nusantara, especially in Riau, was preceded by the entry of Islamic religious culture from Arabia. The Arabians at that time brought their cultures and tried to interact with the surrounding culture. The results of the interaction process made a combination or acculturation between Malay culture and Arabic culture, then this Zapin Dance was formed which was accepted by the two cultural supporters of society. The acculturation of the two cultures still has elements of ethnocentrism that are thick in their respective cultures. Indigenous people, in general, the Malay community, accept the Zapin Dance as a mixed dance between Arabic and Malay, but it raised the Malay side compared to Arabic nuances [2].

Zapin comes from Arabic, namely "Zafn", the word zafn has the meaning of a fast foot movement that follows the beat [3]. Furthermore, Astuti's explanation strengthens the statement that the relationship between Zapin Dance, Arabic, and Islamic art is strengthened in some written statements [3]. It is said that Zapin has the root of the Arabic word "Zafn", which is the movement of the feet quickly following the beat of a punch. The relationship between "Zafn" and Zapin becomes relevant because Zapin itself has a major force in the movement of the legs to the music. So Zapin can be said to be a form of art that uses leg movements as the basis for its tempo. The movement of the legs arises because of an overflow of feelings of joy and joy which is then accompanied by the sound of striking tools [4].

According to Haism Ahmed, the term Zapin appeared around the 6th century, when there was a war with the unbelievers of Mecca, in which at that time Saidina Hamzah's daughter wanted to follow Prophet Muhammad to move to Medina, but Prophet Muhammad refused. This was resulting in a debate, but soon Prophet Muhammad appointed Saidina Ali to be the guardian of Saidina Hamzah's daughter, who later Saidina Ali happily danced with his legs up [3].

Islamic values are attached to Zapin's dance and music performances. Ethics of politeness are presented through a variety of alif movements as an opening and worship. Other signs of Islam are presented through song lyrics that contain Islamic moral advice or teachings. The breath of Islam can be traced and understood based on the content and meaning of the Zapin song lyrics which contain teachings, advice, and preaching that educate or are called teaching points [3].

This suggests that the Zapin dance substances have an edutainment function. On the one hand, it has an educational 
function, which is to become a medium for Islamic preaching. On the other hand, it functions as entertainment, especially when the Zapin dance is used at weddings, circumcisions, festivals, cultural parties, Islamic religion events, or other communal events [3].

Besides having a function for education, it turns out that zapin has a very clear relationship between aesthetics and aspects of art and is the most widely discussed in works of art. Refereeing to the philosophical aspect that Zapin includes alua, patuik, raso, paseo, in the aesthetic study of Zapin Dance which aims to understand the functions and aesthetics, this dance still has relation with the historical and aesthetics of the Riau Zapin Siak Dance [5].

\section{METHODS}

A qualitative approach using descriptive-analytical research methods was applied in this study. Sugiyono said, "Qualitative research methods are often called naturalistic research methods because research is conducted in natural conditions (natural setting); it is also called the ethnographic method because initially this method was more widely used for research in the field of cultural anthropology; it is also known as a qualitative method because the data collected and the analysis are more qualitative in nature" [6].

The formulation of the problem in this research is what is the uniqueness of the Malay Zapin Dance? To dissect this problem, several theoretical foundations were depleted. In general, the theory is rational thinking and a collection of experiences that are empirically proven and consistent so that it can be used to explain, predict, and control the phenomena.

\section{DISCUSSION}

\section{A. Basic Zapin Dance Motion Forms}

- The basic steps for the Zapin Dance begin with the right foot being stomped (smashed into the floor)

- Then the same foot is stepped forward with

- Followed by the left foot stepped forward

- Followed by the right foot forward

- Followed by the left foot forward on the stalk (broken to the floor)

- Stepped the left foot forward

- Followed by the right foot stepped

- Lastly, step left foot forward while turning (rotating 180 degrees), so that it points to its original place.

In other words, the count in the Zapin Dance is 1 to 8 on the count of 1 and 5 feet on the stalk (just cracked) and the next count is just stepped against.

Basically, the basic steps of Zapin Dance are patterned on 1) Forward steps, 2) Backward steps, 3) Twisting steps.
Zapin Dance dancers must master the movements of the various forms of zapin flowers that already exist with standardized names, among which there are several examples; ali, alif smebah, front sutures, backward sutures, back and forth sutures, hanging sutures, first-time sutures, third-day sutures, and many others.

The procedure for dancing the Zapin Siak Dance as described by Zulkifli [7].

The performance begins with two dancers slowly and politely go to the middle of the arena and sitting on their knees (right knee straightened up while left leg kneeled to the floor while both hands salute to the front, with their head or gaze straight ahead.

The gambus music is played, Marwas also acted, the dancer slowly stands up with the position of the feet slightly closer together. The left hand is lifted at the elbow (forming elbows) while the right-hand goes down. The dancer has not started the dance before the gambus player makes his voice through the song of his choice.

As soon as the player of the gambus sings the song, the dancer starts the dance with the alif movement (alif sembah) or other alif forms according to the calculation as the movement above is continued with basic steps forward and back to the original place.

The position of the dancer stepping forward to the front is called the "up" direction, and when the direction of the step returns to the original place, it is called "down".

Zapin flowers are done when they go up, and when they go down, they usually take basic steps, but some do Zapin flowers when they go down and this is called zapin vengeance.

The zapin flowers that are danced appear spontaneously from the two dancers who are contented when the step is down, then moved when they go up.

Every dancer must master various kinds of zapin flowers. When they are dancing the zapin, the body position is upright (not bending), except at certain times such as making eagle flowers grabbing, or when turning. When stepping the foot, knees are slightly bent and the body compensates for footwork (such as flowing) the footsteps are not too wide nor too high.

If the dancer wants to stop the dance then he makes a zapin flower gesture for tahto, which is especially displayed when it is about to stop (as a code for the musician).

As soon as the musician sees the movement of this tahto flower, the musician gives a special musical rhythm that is also used for tahto.

Simultaneously with this tahto music, the dancers make zapin tahto flowers. The music stops and the dance is finished. Then the dancer sits back to its original place. A zapin siak dance performance was finished. 


\section{B. Zapin Dance Accompaniment}

The Malay zapin music is characterized by the melody of the lute instrument, while the marwas drum beat adds to the distinctiveness of the music so that the strikes are muttered and produce a harmonious sound. Malay Zapin music has a simple form and pattern, both the equipment of the musical instruments and the procedures for the rules of the game so that it is easily recognized and integrated with people who really uphold their customs. Besides that, the reason for its rapid development is because it has a religious style and breath. This is because the song contains advice, messages, and trust.

According to the Jakarta Arts Council, the term rentak is known in the Malay dance, which is a certain rhythmic (musical) underlying certain motives of motion. Rentak is what builds the atmosphere and identity of the Malay dance [5].

\section{The Philosophy Contained in the Zapin Dance}

Zapin dance is seen from a philosophical aspect according to the explanation from Indah, Alua, adapted to the customs where the dance can develop. Alua can be said to put something in its place [8]. Alua in dance can be seen from how the dance is placed, such as an example of ethics that the Zapin Dance was not previously danced by women, then it has certain rules such as not being allowed to raise your hands too high.

\section{Uniqueness}

The uniqueness of Zapin Dance can be seen from the movements performed by the panrinya, they are not just ordinary movements, but these movements have their own meaning. For example, praying alif is one of the names of the first motion or what is called the opening greeting, this movement is done by making a straight line back and forth according to the count, then turning the whole body. This movement has the meaning of an attitude of inferiority and respect for the guests who are present.

Another uniqueness that can be seen in the movements of the panri is that they are not accustomed to rocking their hips, even though they have now developed as a performing art, but still have the aim of educating the manners of dancers in front of the audience [9]

According to Noor, there are various philosophies stored in the art of offerings and one of the main Malay philosophies is simplicity [10]. This philosophy can also be lived in in the Zapin Dance in terms of dance movements, music, and Zapin clothing. The dance movements are divided into footsteps, body positions, and swings and arms. The footsteps of the Zapin dancer are only as wide as the plane of the feet and not as wide as the calves so that the cloth used can be tucked apart so that the calf of the foot is exposed. The soles of the feet are not raised too high nor are they held anywhere to prevent the viewers from seeing the soles of the feet. The simplicity of this step gives birth to the beauty of the softness of the footing and footsteps [10].

Investigating from the point of view of the choreography, the Zapin Dance movement is very simple, but has several meanings from which the researcher find out something unique in the Zapin dance choreography. Apart from the uniqueness that has been mentioned above, the uniqueness that is obtained is the simple footwork that has made Zapin Dance flourish until now.

\section{CONCLUSION}

From the explanation above, it can be concluded that the Zapin Dance movement relies heavily on the foot movements that follow the beat of the music. The movements of the Zapin Dance are very simple because they only use the lute and marwas as accompaniment. There are more repetitive movements in this dance such as forward steps, backward steps, and rotations, besides that these movements are also the basic movements of the dance.

From the simplicity and movement of the feet that have a stomping foot so that it becomes the researchers' interest because Zapin Dance has been known widely starting only from simple movements. This makes the researcher consider the Zapin Dance can be classified into unique dance performance in terms of its footwork.

\section{REFERENCES}

[1] D.I.P. Sari, Reconstruction of the Zapin 12 Traditional Dance of Kuala Kampar at the Panglima City Center of Pangkalan Kerinci, Pelalawan Regency, Riau. Bandung: University of Pendidikan Indonesia, 2015.

[2] S. Sarita, I. Isjoni, and K. Kamaruddin, "History of Zapin Dance in Meskom Village, Bengkalis District, Bengkalis Regency," Student Online Journal of the Faculty of Teacher Training and Education, vol. 2, no. 2, 2015 .

[3] S.V. Astuti, Tari zapin bengkalis: bentuk, karakteristik, dan perkembangan. Surakarta: Institut Seni Indonesia Surakarta, 2016.

[4] E. Roza and N.A. Zulkifli, "The contribution of zapin as one of malay traditional arts in curriculum 2013," Al-Ta lim Journal, vol. 24, no. 2, pp. 142-156, 2017.

[5] I.Y. Indah, E.E. Ediwar and M.M. Martion, "Estetika Tari Zapin sebagai Sumber Penciptaan Karya Kaki-kaki,” Bercadik: Jurnal Pengkajian dan Penciptaan Seni, vol. 1, no. 1, 2017.

[6] Sugiyono, Educational Research Methods. Bandung: Alfabeta, 2019.

[7] Z.A. Zulkifli, Zapin Siak dance moves. Siak Sri Indrapura, 2013.

[8] Daryusti, Circle of Genius and Cultural Art Thought. Yogyakarta: Cipta Media, 2010.

[9] D.A.S. Tiba, T. Supadmi, and T. Hartati, "Bentuk Penyajian Tari Zapin Pekajang di Sanggar Buana Kota Banda Aceh," Jurnal Ilmiah Mahasiswa Pendidikan Seni, Drama, Tari \& Musik, vol. 1, no. 3, pp. 221-228, 2016.

[10] W.M. Fauzan, W.M. Afiq, and S.K.S. Husain, "Geometry In Zapin Dance," Asian Journal of Environment: History and Heritage, vol. 2, no. 2, 331-342, 2018. 